\title{
PENERAPAN METODE PEMBELAJARAN DISCOVERY DALAM MENINGKATKAN PRESTASI BELAJAR IPA PADA PESERTA DIDIK KELAS IV DI SEKOLAH DASAR
}

\author{
Suryadin Hasyda \\ Program Studi PGSD \\ Universitas Muhammadiyah Kupang \\ E-mail: suryadinhasyda92@gmail.com
}

\begin{abstract}
Abstrak
Tujuan dari penelitian ini adalah untuk meningkatkan prestasi belajar IPA pada peserta didik melalui model pembelajaran discovery kelas IV SD Inpres Watumoto. Jenis penelitian yang digunakan dalam penelitian ini adalah penelitian tindakan kelas yang terdiri dari beberapa siklus yang saling berkaitan, dan model yang dipilih dalam penelitian ini adalah model Kemis dan Mc Tagart yang terdiri dari beberapa tahap yakni perencanaan, tindakan, pengamatan dan refleksi. Dimana tindakan dan pengamatan dilaksanakan secara bersama. Apabila siklus pertama belum mencapai tujuan yang ditargetkan maka dilanjutkan dengan siklus kedua yaitu perbaikan rencana, tindakan, observasi, dan refleksi. Subjek penelitian ini adalah siswa kelas IV SD Inpres Watumoto. Teknik pengumpulan data dalam penelitian adalah tes dan non tes. Instrumen pengumpulan data yang digunakan adalah lembar observasi untuk memperoleh data keterlaksanaan pembelajaran dan tes prestasi belajar IPA. Berdasarkan hasil analisis data dalam penelitian tindakan kelas bahwa hasil penelitian menunjukan bahwa metode pembelajaran discovery dapat meningkatkan aktivitas dan prestasi belajar peserta didik, hal ini dilihat dari hasil observasi aktivitas peserta didik siklus I mencapai rata-rata 72,38 dan siklus ke II dengan nilai rata-rata 83,69. Sedangkan test prestasi belajar peserta didik siklus I dengan presentase ketuntasan $60 \%$ dan siklus ke II $100 \%$ dengan catatan tuntas secara klasikal. Nilai tertinggi yang diperoleh peserta didik adalah 100 dan nilai terendah 70 dengan nilai rata-rata $84,61 \%$. Oleh sebab itu, pelaksanaan penelitian dengan menerapkan model pembelajaran discovery diakhiri pada siklus II. Jadi, melalui penelitian yang telah dilakukan dengan menerapkannya metode pembelajaran discovery, terbukti dapat meningkatkan prestasi belajar peserta didik kelas IV yang hasil tes prestasi belajar tuntas atau memenuhi kriteria ketuntasan minimal (KKM).
\end{abstract}

Kata kunci:

Metode Pembelajaran

Discovery, Prestasi

Belajar, Pembelajaran

IPA

\begin{abstract}
The purpose of this study is to improve the science learning achievement of students through discovery learning model class IV SD Inpres Watumoto. This type of research used in this research is classroom action research consisting of several interrelated cycles, and the model chosen in this study is the Kemis and Mc Tagart model which consists of several stages namely planning, action, observation and reflection. Where actions and observations are carried out together. If the first cycle has not achieved the targeted goals, then the second cycle is continued, namely improvement of plans, actions, observations, and reflections. The subjects of this study were students in grade IV SD Inpres Watumoto. Data collection techniques in research are tests and non-tests. The data collection instrument used was an observation sheet to obtain data on the feasibility of learning and natural science achievement test. Based on the results of data analysis in classroom action research that the research results show that discovery learning methods can improve students' learning activities and achievement, this is seen from the observations of the activities of students in cycle I reaching an average of 72.38 and cycle II with average values average 83.69. While the learning achievement test for students in cycle I with a percentage of completeness of $60 \%$ and cycle II in $100 \%$ with classical completion notes. The highest value obtained by students is 100 and the lowest value is 70 with an average value of $84.61 \%$. Therefore, the implementation of research by applying discovery learning models ends in cycle II. So, through research that has been done by applying the discovery learning method, it is proven that it can improve the learning achievement of fourth grade students who have completed learning achievement tests or meet the minimum completeness criteria (KKM).
\end{abstract}


Keywords: Discovery Learning Method, Learning Achievement, Science Learning

\section{PENDAHULUAN}

Sistem pendidikan di Indonesia ternyata masih mengalami banyak permasalahan. Salah satu masalah yang dihadapi dunia pendidikan kita adalah masalah lemahnya proses pembelajaran. Dalam proses pembelajaran, anak kurang didorong untuk mengembangkan kemampuan berpikir. Proses pembelajaran di dalam kelas diarahkan kepada kemampuan anak untuk menghafal informasi, otak anak dipaksa untuk mengingat dan menimbun berbagai informasi tanpa dituntut untuk memahami informasi yang diingatnya itu untuk menghubungkannya dengan kehidupan sehari-hari. Akibatnya, ketika anak didik lulus dari sekolah, mereka pintar secara teoritis, tetapi mereka miskin aplikasi. UU Republik Indonesia Nomor 20 Tahun 2003 tentang Sistem Pendidikan Nasional menyatakan bahwa pendidikan adalah usaha sadar dan terencana untuk mewujudkan suasana belajar dan proses pembelajaran agar peserta didik secara aktif mengembangkan potensi dirinya untuk memiliki kekuatan spiritual keagamaan, pengendalian diri, kepribadian, kecerdasan, akhlak mulia, serta keterampilan yang diperlukan dirinya, masyarakat, bangsa, dan negara (Sanjaya, 2006: 2).

Secara umum fungsi lingkungan pendidikan adalah membantu peserta didik dalam berinteraksi dengan berbagai lingkungan sekitarnya (fisik, sosial, dan budaya), utamanya berbagai sumber daya pendidikan yang tersedia, agar dapat dicapai tujuan pendidikan yang optimal. Penata lingkungan pendidikan itu terutama dimaksudkan agar proses pendidikan dapat berkembang efisien dan efektif. Oleh karena itu diperlukan berbagai usaha sadar untuk mengatur dan mengendalikan lingkungan itu sedemikian rupa agar dapat diperoleh peluang pencapaian tujuan secara optimal. Dengan demikian diharapkan mutu sumber daya manusia makin lama semakin meningkat. Hal itu dapat diwujudkan apabila setiap lingkungan pendidikan tersebut dapat melaksanakan fungsinya sebagaimana mestinya (Tirtarahardja, 2008:164).

Namun demikian, komponen yang selama ini dianggap sangat mempengaruhi proses pendidikan adalah guru. Hal ini memang wajar, sebab guru merupakan ujung tombak yang berhubungan langsung dengan peserta didik sebagai subjek dan obyek belajar. Oleh karena itu, seorang guru harus memilih strategi atau cara yang tepat dalam melaksanakan pembelajaran agar diperoleh peningkatan prestasi belajar peserta didik khususnya pelajaran IPA. Pendidikan IPA diharapkan dapat menjadi wahana bagi peserta didik untuk mempelajari diri sendiri dan alam sekitar serta prospek pengembangan lebih lanjut dalam menerapkannya didalam kehidupan sehari-hari. Proses pembelajarannya menekankan pada pemberian pengelaman langsung untuk mengembangkan kompetensi agar menjelajahi dan memahami alam sekitar secara ilmiah (Trianto, 2007: 99).

Kenyataan yang ada di SD Inpres Watumoto, bahwa pembelajaran yang diberikan kepada peserta didik hanya mengacu kepada pembelajaran kognitif dengan menggunakan metode ceramah, mengemukakan pendapat, bertanya, dan memberikan latihan atau penugasan. Pembelajaran yang digunakan masih bersifat monoton (kurang bervariasi). Proses pembelajarannya hanya terpusat pada guru, sehingga daya ingat atau menyimpan informasi yang diperolehnya lemah dan hasilnya tidak memuaskan atau tidak sesuai dengan KKM yang telah ditentukan di sekolah (nilai KKM 65). Hal itu dilihat dari 13 anak yang mengikuti pelajaran, ada 5 peserta didik yang tidak tuntas.

Berdasarkan fakta tersebut, maka peneliti memilih cara dengan menggunakan metode pembelajaran discovery dalam meningkatkan prestasi belajar peserta didik. Metode pembelajaran discovery merupakan suatu cara mengajar yang melibatkan peserta didik dalam proses kegiatan mental melalui tukar pendapat, diskusi, membaca sendiri dan mencoba sendiri, agar anak dapat belajar sendiri dan dapat memberikan inovatif untuk meningkatkan proses pembelajaran karena metode discovery ini memiliki karakteristik yaitu, adanya kerja sama antar kelompok, siswa aktif dan guru kreatif (Jufri, 2013: 22). Berdasarkan latar 
belakang di atas, maka penulis dalam penelitian ini mengambil judul "Penerapan metode pembelajaran discovery dalam meningkatkan prestasi belajar IPA pada peserta didik kelas IV di sekolah dasar".

\section{METODE}

Jenis penelitian ini adalah penelitian tindakan kelas. Penelitian tindakan kelas adalah penelitian yang dilakukan oleh guru di dalam kelasnya sendiri melalui refleksi, dengan tujuan untuk memperbaiki kinerja sebagai guru sehingga prestasi belajar peserta didik menjadi meningkat (Wardhani dkk, 1.4: 2007). Menurut Kemmis (Wiriaatmadja, R. 2009: 12) Penelitian tindakan kelas adalah sebuah bentuk inkuiri refleksi yang dilakukan secara kemitraan mengenai situasi sosial tertentu (termasuk pendidikan) untuk meningkatkan rasionalitas dan keadilan dari: a) Kegiatan praktek sosial atau pendidikan mereka, b) Pemahaman mereka mengenai kegiatan-kegiatan praktek pendidikan ini, c) Situasi yang memungkinkan terlaksananya kegiatan praktek ini.

Ebbutt (Wiriaatmadja, R. 2009: 12) mengemukakan penelitian tindakan kelas merupakan kajian sistematik dari upaya perbaikan pelaksanaan praktek pendidikan oleh sekelompok guru dengan melakukan tindakan-tindakan dalam pembelajaran, berdasarkan refleksi mereka mengenai hasil dari tindakan-tindakan tersebut. Pelaksanaan penelitian tindakan kelas menggabungkan tindakan bermakna dengan prosedur penelitian yang merupakan suatu upaya memecahkan sekaligus mencari dukungan ilmiah. Kesimpulan dari penelitian tindakan kelas adalah peneliti yang melakukan tindakan-tindakan tertentu agar dapat memperbaiki atau meningkkatkan kualitas pembelajaran. Dalam penelitian ini prosedur penelitian tindakan kelas ini terdiri dari dua siklus. Tiap-tiap siklus dilaksanakan sesuai dengan perubahan yang ingin dicapai.

\section{Prosedur Penelitian}

Rancangan yang ditetapkan dalam penelitian ini adalah penelitian tindakan kelas. Tahapan penelitian ini adalah sebagai berikut: Penelitian tindakan kelas dilaksanakan dalam bentuk siklus yang terdiri dari 3 tahap yaitu perencanaan, tindakan dan observasi, refleksi.

Gambar 3.1 Bagan siklus pembelajaran model Kemmis dan Mc Taggart 


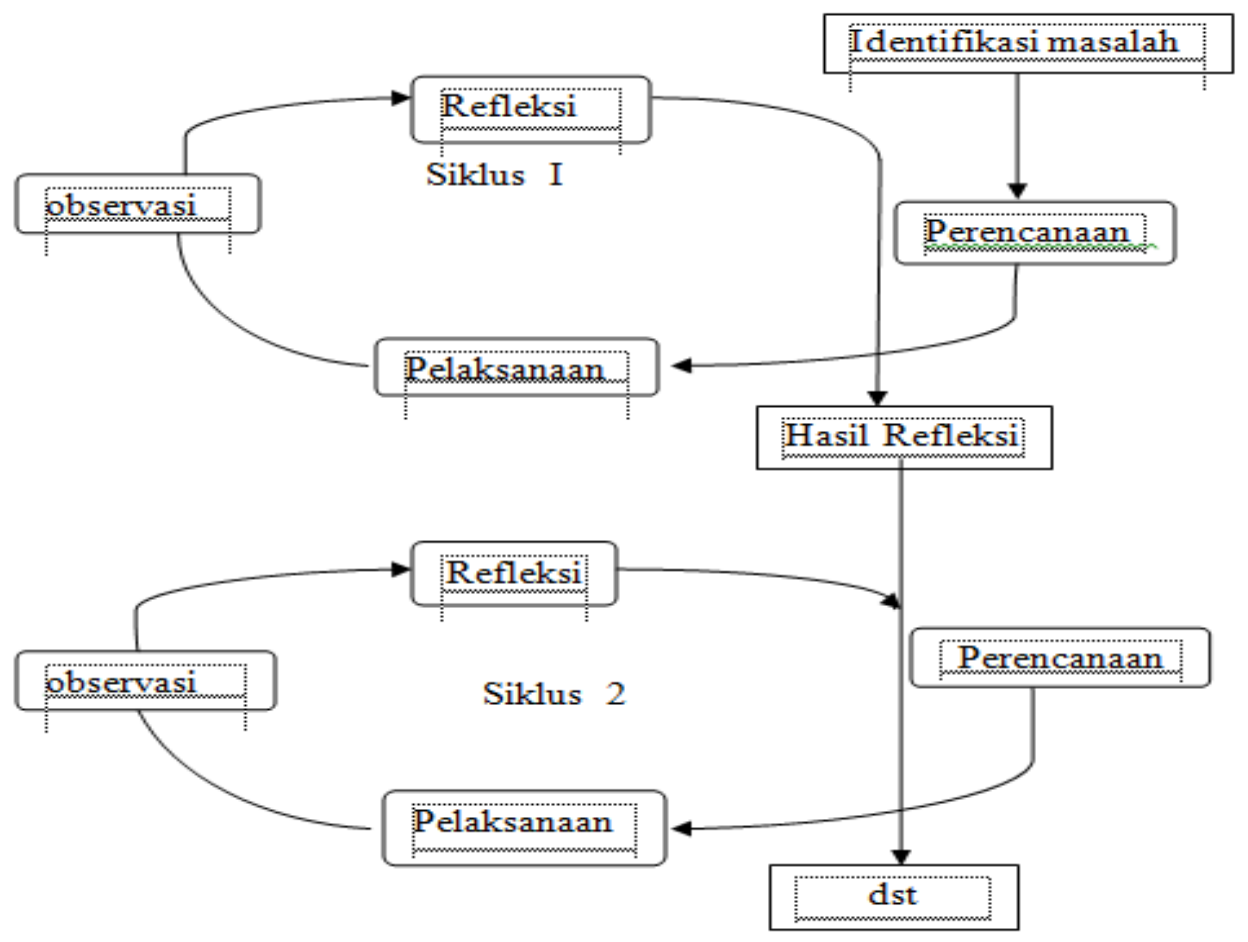

\section{Setting Penelitian}

Penelitian tindakan kelas ini dilakukan di SD Inpres Watumoto Kabupaten Ende pada bulan September tahun 2018, di mana waktu penelitian mengacu pada penentuan kalender akademik sekolah, karena PTK memerlukan beberapa siklus yang membutuhkan proses belajar mengajar secara efektif di kelas.

\section{Subjek Penelitian}

Subjek penelitian dalam PTK ini adalah peserta didik Kelas IV SD Inpres Watumoto yang berjumlah 13 orang dengan umur rata-rata 9-10 tahun, laki-laki berjumlah 8 orang dan perempuan 5 orang.

\section{Teknik Pengumpulan Data}

Teknik pengumpulan data yang dilakukan pada penelitian ini adalah teknik wawancara, teknik observasi, teknik tes prestasi belajar, dan studi dokumen.

\section{Teknik Analisa Data}

Data yang dibutuhkan dalam PTK ini diperoleh dengan instrumen ukur tes untuk memperoleh data hasil belajar, dan instrumen observasi untuk mengukur aktivitas proses pembelajaran.

\section{Teknik Analisa Data Observasi}

Untuk menghitung lembar observasi aktivitas guru dan siswa digunakan rumus sebagai berikut:

$$
\%=\frac{X}{\sum X} X 100 \%
$$

Tingkat keberhasilan ditentukan dengan menggunakan kriteria penilaian sebagai berikut: 


\begin{tabular}{|c|c|c|c|}
\hline No & Tingkat Keberhasilan & Nilai & Keterangan \\
\hline 1. & $91-100$ & A & Baik Sekali \\
\hline 2. & $81-90$ & B & Baik \\
\hline 3. & $71-80$ & C & Cukup \\
\hline 4. & $61-70$ & D & Kurang \\
\hline 5. & $0-60$ & E & Kurang Sekali \\
\hline
\end{tabular}

Sumber: Daryanto (2011: 192).

2. Teknik Analisis Data Tes

Peneliti melakukan penjumlahan nilai yang diperoleh peserta didik, yang selanjutnya dibagi dengan jumlah peserta didik yang ada dikelas tersebut sehingga diperoleh rata-rata tes formatif dapat dirumuskan:

$$
\bar{x}=\frac{\Sigma}{\Sigma} \quad x
$$

\section{HASIL DAN PEMBAHASAN}

\section{Hasil keterlaksanaan pembelajaran dan aktivitas peserta didik dalam penerapan metode pembelajaran Discovery}

Keterlaksanaan pembelajaran dan akativitas siswa selama proses pembelajaran dengan menerapkan metode pembelajaran discovery diamati dan ditulis hasil pengamatannya didalam lembar pengamatan oleh observer. Secara ringkas data hasil keterlaksanaan dan aktivitas peserta didik dalam pembelajaran dengan menerapkan metode pembelajaran discovery dipaparkan pada tabel berikut ini.

Tabel 1. Hasil keterlaksanaan pembelajaran dan aktivitas peserta didik pada siklus I dan II

\begin{tabular}{|l|l|c|c|}
\hline \multirow{2}{*}{ No } & \multicolumn{1}{|c|}{ Instrumen } & \multicolumn{2}{|c|}{ Keterlaksanaan } \\
\cline { 3 - 4 } & & Siklus I & Siklus II \\
\hline 1. & Hasil Observasi Keterlaksanaan Pembelajaran & $78,57 \%$ & $89,28 \%$ \\
\hline 2. & Hasil Observasi Aktivitas Siswa & $72,38 \%$ & $83,69 \%$ \\
\hline
\end{tabular}

Data keterlaksanaan pembelajaran dan aktivitas peserta didik diperoleh dengan observasi selama pembelajaran berlangsung. Berdasarkan tabel 1 diatas bahwa penilaian pengamat diperoleh nilai keterlaksanaan pembelajaran siklus I 78,57\% dengan kategori cukup baik dan siklus II 89,28\% dengan kategori baik. Sedangkan aktivitas peserta didik pada siklus I 72,38 \% dengan kategori cukup baik, dan siklus II 83,69 \% dengan kategori baik, nilai yang diperoleh selalu meningkat di setiap siklusnya. Selanjutnya peneliti juga menyajikan dalam bentuk diagram berikut ini. 


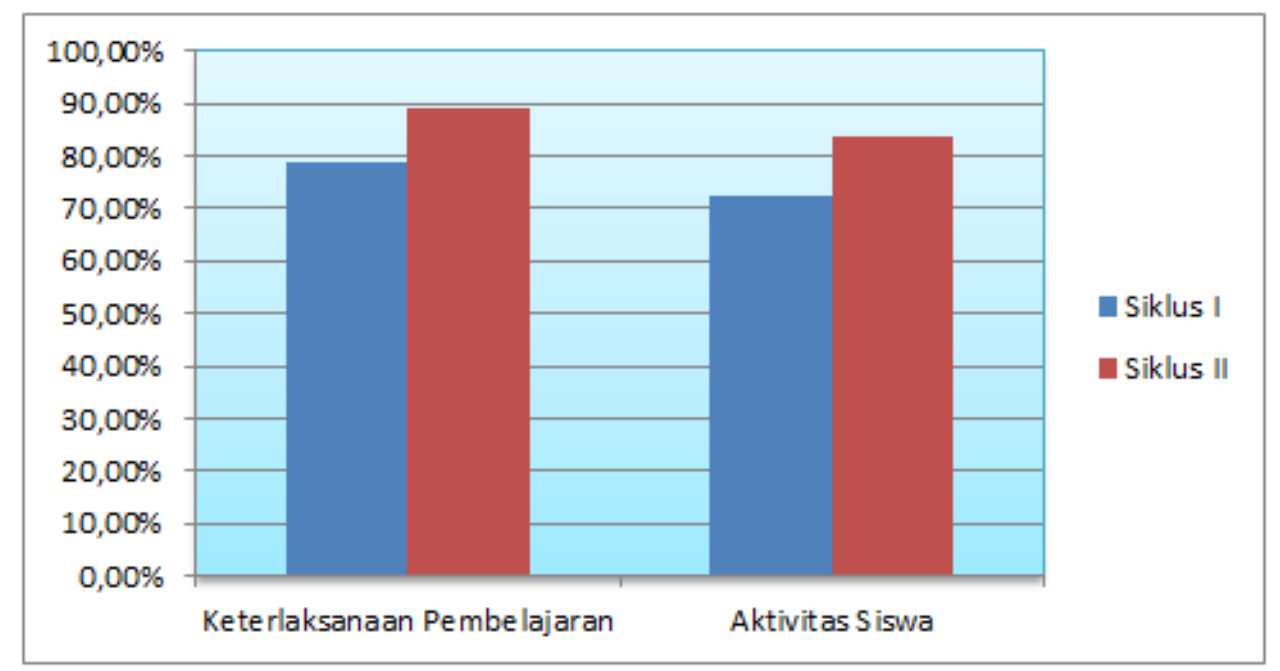

Diagram 1. Hasil Keterlaksanaan Pembelajaran dan Aktivitas Peserta Didik

Dari diagram diatas, terlihat bahwa keterlaksanaan pembelajaran dan aktivitas peserta didik selalu mengalami peningkatan disetiap siklusnya. Sehingga dapat ditarik kesimpulan bahwa model pembelajaran discovery dapat meningkatkan aktivitas keterlaksanaan pembelajaran dan aktivitas peserta didik telah mencapai indikator keberhasilan dan meningkat setiap silkusnya. Hal tersebut menunjukan bahwa keterlaksanaan pembelajaran dan aktivitas peserta didik dalam menerapkan metode pembelajaran discovery sudah baik.

\section{Hasil Tes Prestasi Belajar Peserta Didik pada siklus I dan II}

Setelah kegiatan pembelajaran berlangsung, diketahui bahwa peserta didik dapat menambah pengalaman yang lebih dibandingkan dengan pembelajaran yang hanya menggunakan metode ceramah/konvensional. Pada kegiatan inti, guru membagikan soal untuk mengukur sejauh mana peserta didik memahami materi tentang perubahan wujud benda setelah melakukan pembelajaran dengan menerapkan model pembelajaran discovery. Semua peserta didik tampak serius dalam mengerjakan soal yang diikuti oleh 13 peserta didik pada siklus I dan siklus II. Setelah semua peserta didik selesai mengerjakan, guru menutup pembelajaran kemudian memberi salam. Skor rata-rata hasil tes prestasi belajar peserta didik pada siklus I dan II dapat dilihat pada tabel berikut ini:

Tabel 2. Hasil tes prestasi belajar peserta didik pada siklus I dan II

\begin{tabular}{|c|c|c|}
\hline No & Siklus I & Siklus II \\
\hline 1 & $60 \%$ & $100 \%$ \\
\hline
\end{tabular}

Berdasarkan tabel diatas diketahui bahwa tes prestasi belajar peserta didik secara klasikal untuk siklus I dengan nilai rata-rata $60 \%$ dengan kategori kurang sekali. Sedangkan siklus II tes prestasi belajar peserta didik secara klasikal diperoleh nilai rata-rata $100 \%$ dengan kategori baik sekali dan sudah tercapai KKM yang ditentukan di sekolah tersebut. Terlihat adanya peningkatan tes prestasi belajar peserta didik pada siklus II dengan menerapkan metode pembelajaran discovery. Secara ringkas tes prestasi belajar peserta didik dapat dilihat pada diagram di bawah ini. 


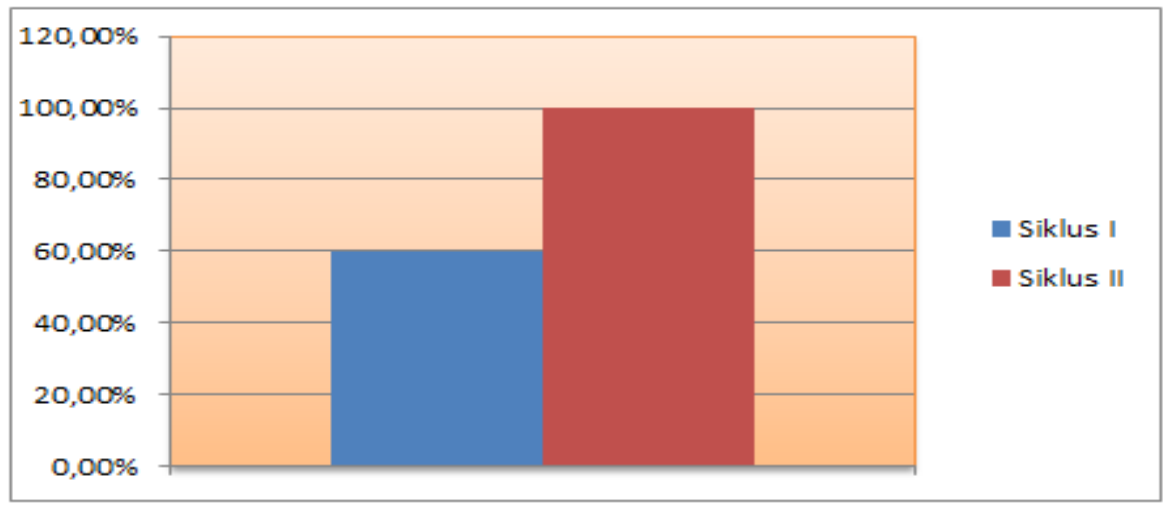

Diagram 2. Hasil Tes Prestasi Belajar Peserta Didik Secara Klasikal Siklus I dan II

Berdasarkan diagram diatas, hasil tes prestasi belajar peserta didik pada siklus II diketahui bahwa sebanyak 13 peserta didik (100\%) sudah berhasil memenuhi kriteria. Oleh sebab itu, pelaksanaan perbaikan siklus ini dapat diakhiri pada siklus II. Jadi, melalui penelitian yang telah dilakukan dengan menerapkan metodel pembelajaran discovery, terbukti dapat meningkatkan prestasi belajar peserta didik kelas IV yang hasil tesnya tuntas atau memenuhi KKM yang ditentukan.

\section{PEMBAHASAN}

Berdasarkan penjelasan pada bagian sebelumnya yang menyatakan bahwa penerapan metode pembelajaran discovery merupakan suatu kegiatan belajar yang melibatkan peserta didik dalam proses kegiatan mental melalui tukar pendapat, diskusi, seminar, membaca sendiri dan mencoba sendiri agar anak dapat belajar sendiri, dan merumuskan sendiri penemuannya dengan percaya diri. Dengan menerapkan metode pembelajaran discovery peserta didik akan berperan aktif untuk mencari dan menemukan sendiri. Hal ini didukung dengan hasil observasi aktivitas peserta didik dan hasil observasi keterlaksanaan pembelajaran yang menunjukan adanya peningkatan yakni: aktivitas peserta didik siklus I dengan rata-rata $72,38 \%$ dengan predikat cukup, siklus II dengan rata-rata 83,69\% dengan predikat baik. Sedangkan hasil observasi keterlaksanaan pembelajaran siklus I 78,57\% dengan predikat cukup dan siklus II 89,28\% dengan predikat baik. Hal ini juga sejalan dengan prinsip belajar yang menekan pada aktivitas siswa yang dikemukakan oleh (Sumiati 2011: 43) yakni: a) Belajar dapat terjadi dengan proses mengalami. Hanya belajar yang berhubungan dengan kegiatan dan pengalaman dapat menyebabkan terjadinya perubahan tingkah laku. b) Belajar merupakan transaksi aktif. Untuk belajar berpikir logis, seseorang tidak hanya menggunakan argumentasi logis, atau menguasai suatu materi pembelajaran yang disusun secara logis, melainkan perlu melakukan kegiatan yang bersifat aktif. c) Belajar secara aktif memerlukan kegiatan yang bersifat vital, sehingga dapat berupaya mencapai tujuan dan memenuhi kebutuhan pribadinya. d) Belajar terjadi melalui proses mengatasi hambatan (masalah) sehingga mencapai pemecahan atau tujuan. e) Hanya dengan melalui penyodoran masalah memungkinkan diaktifkannya motivasi dan upaya, sehingga siswa berpengalaman dengan kegiatan yang bertujuan.

Teori belajar kognitif serta prinsip-prinsip belajar sebagaimana dikemukakan di atas, menjadi landasan dalam proses belajar untuk mencapai hasil dalam bentuk apapun. Pemahaman yang menjadi inti dari teori belajar ini, bukan hanya melandasi kemampuankemampuan kognitif, tetapi juga melandasi berbagai kemampuan psikomotor (keterampilan), bahkan dengan diperolehnya kemampuan kognitif dan psikomotorik yang tinggi dapat memberi pengaruh terhadap pembentukan sikap. Berdasarkan landasan teori di atas maka dalam penerapan metode pembelajaran discovery lebih menekankan pada intelektual peserta didik, dan aktivitas peserta didik, artinya metode pembelajaran discovery selain berorientasi 
pada prestasi belajar peserta didik tetapi juga berorientasi pada proses belajar. Oleh karena itu kriteria keberhasilan dari proses pemebelajaran dengan menerapkan metode discovery bukan ditentukan sejauh mana peserta didik menguasai materi pelajaran, akan tetapi sejauh mana peserta didik beraktivitas mencari dan menemukan. Dalam siklus I, Hasil test pesrta didik mencapai $60 \%$ atau berpredikat kurang, sedangkan aktivitas peserta didik mencapai $72,38 \%$ atau berpredikat cukup. Hal ini dikarenakan proses pembelajaran masih berorientasi pada guru atau teacher centered. Peserta didik belum terlibat aktif dalam kegiatan belajar dengan menerapkan metode pembelajaran discovery, karena masih banyak peserta didik yang belum terlibat dalam melakukan pengamatan.

Sedangkan pada siklus II, peserta didik menjadi lebih aktif dalam mencari dan menemukan materi pembelajaran. Hal ini ditandai dengan kenaikan hasil test peserta didik menjadi $100 \%$ atau berpredikat baik sekali, dan aktivitas peserta didik menjadi $89,69 \%$ atau berpredikat baik. Peserta didik menjadi aktif karena proses pembelajaran discovery peserta didik diberi kebebasan untuk menemukan dan mencari informasi. Peserta didik diberi kebebasan untuk mengungkapkan, menyusun dan menyimpulkan hasil pengamatannya. Proses ini disusun melalui langkah-langkah pembelajaran yang telah disusun oleh peneliti. Selain itu, proses pembelajaran discovery juga dapat membuat peserta didik menjadi lebih fokus terhadap apa yang akan dipelajari dan hasil yang akan dicapai setelah proses pembelajaran terjadi.

Peningkatan prestasi belajar peserta didik ini membuktikan bahwa penerapan metode pembelajaran discovery sejalan dengan teori belajar yang diusulkan oleh Brunner yang disebut belajar melalui investigasi bebas (free discovery learnig). Menurut teori ini, proses belajar akan dapat berlangsung dengan aktif, kreatif, efektif dan menyenangkan jika pendidik memberikan kesempatan kepada peserta didik untuk menemukan. Belajar melalui proses mencari dan menemukan (discovery inquiry learning) merupakan pengajaran yang dikembangkan berdasarkan pada pandangan kognitif tentang pembelajaran dan prinsip-prinsip konstruktivistik. Dalam discovery learning peserta didik didorong untuk belajar secara mandiri melalui keterlibatan aktif dengan konsep-konsep dan prinsip-prinsip. Dengan kata lain, discovery terjadi apa bila peserta didik terlibat secara aktif dalam menggunakan proses mentalnya agar mereka memperoleh pengalaman, sehingga memungkinkan mereka untuk menemukan beberapa konsep atau prinsip tersebut.

\section{KESIMPULAN}

Berdasarkan rumusan masalah dan hasil penelitian yang telah dibahas sebelumnya, maka dapat ditarik kesimpulan sebagai berikut; Kesatu, Penerapan metode pembelajaran discovery dapat merangsang peserta didik untuk aktif dalam belajar. Melalui kegiatan pengamatan atau eksperimen peserta didik dapat melakukan penemuan terhadap suatu masalah dan belajar memecahkan masalah sendiri dengan keterampilan yang dimilikinya. Hal ini dapat meningkatkan aktivitas dalam proses pembelajaran, baik itu keterlaksanaan pembelajaran maupun aktivitas peserta didik dalam mengikuti rangkain pembelajaran. Hal ini terjadi karena dalam penerapan metode pembelajaran discovery sudah terlaksana dengan baik. Kedua, Penerapan metode pembelajaran discovery dapat meningkatkan prestasi belajar peserta didik. Hal ini dibuktikan dengan adanya peningkataan pada prestasi belajar peserta didik dari siklus I ke siklus II. Hal ini terlihat dari persentase ketuntasan pada siklus I sebesar $60 \%$ dan siklus II sebesar $100 \%$. Dari hasil persentase ketuntasan tersebut, terlihat jelas bahwa melalui metode pembelajaran discovery dapat meningkatkan perstasi belajar peserta didik.

\section{DAFTAR PUSTAKA}


Daryanto. (2011). Penelitian Tindakan Kelas dan Penelitian Tindakan Sekolah. Yogyakarta: Gava Media.

Hamdani. (2011). Strategi Belajar Mengajar. Bandung: Pustaka Setia.

Jufri, Wahab. (2013). Belajar dan Pembelajaran SAINS. Bandung: Pustaka Reka Cipta.

Roestiyah. (2012). Strategi Belajar Mengajar. Jakarta: Rineka Cipta.

Sanjaya, Wina. (2006). Strategi Pembelajaran Berorientasi Standar Proses Pendidikan. Jakarta: Kencana Prenada Media Group.

Sukmadinata, N, Syaodih. (2010). Metode Penelitian Pendidikan. Bandung: Remaja Rosdakarya Offset.

Sumiati. (2011). Metode Pembelajaran. Bandung: Wacana Prima.

Tirtarahardja, Umar. 2008. Pengantar Pendidikan. Jakarta: Asdi Mahasatya.

Trianto. (2007). Model Pembelajaran Terpadu dalam Teori dan Praktek. Jakarta: Prestasi Pustaka.

Wardhani, dkk. (2007). Penelitian Tindakan Kelas. Jakarta: Universitas Terbuka.

Wiriaatmadja, R. (2009). Metode Penelitian Tindakan Kelas. Bandung: Remaja Rosdakarya Offset. 